Caribbean Routes: Ethnographic Experiences, Theoretical Challenges, and the Production of Knowledge

\title{
(Extra)ordinary help: \\ untold stories on disaster and generosity in Grand'Anse, Haiti
}

\author{
Ana Elisa de Figueiredo Bersani ${ }^{1}$ \\ ' Universidade Estadual de Campinas, Programa de Pós-graduação em Antropologia Social, \\ Campinas/SP, Brasil
}

\begin{abstract}
The article situates the theme of help and generosity by examining responses of communities in Grand'Anse province to the 2010 disaster in Haiti. This emblematic case reveals how oft-unmentioned familial and community mechanisms that go beyond the reach of state and international institutions were essential to the survival of Haitians, and constituted a highly effective emergency response, despite the scarcity of resources and despair caused by the destruction. Drawing on the literature on humanitarian aid and development, through a processual approach, I suggest that the ways in which Haitian society dealt with the aftermath question the notions of disaster and help, offering unique guidance about how the problems and challenges presented by critical events might be addressed more effectively.
\end{abstract}

Key words: Disaster; Haiti; generosity; improvisation. 


\section{O (extra)ordinário da ajuda: Histórias não contadas sobre desastre e generosidade na Grand'Anse, Haiti}

\section{Resumo}

$\mathrm{O}$ artigo descreve o tema da ajuda e da generosidade, examinando a resposta comunitária ao desastre de 2010 na Grand'Anse, Haiti. Este caso emblemático revela como os mecanismos familiares e comunitários que vão além do alcance das instituições estatais e internacionais foram essenciais para a sobrevivência dos haitianos e constituíram uma resposta a emergência altamente eficaz, apesar da escassez de recursos e do desespero causados pela destruição. Com base na literatura sobre ajuda humanitária e desenvolvimento e por meio de uma abordagem processual, sugiro que as maneiras pelas quais a sociedade haitiana lidou com as consequências colocam em questão as noções de desastre e ajuda, oferecendo orientação única sobre como os problemas e desafios apresentados por eventos críticos podem ser tratados com mais eficácia.

Palavras-chave: desastre; Haiti; generosidade; improviso. 


\title{
(Extra)ordinary help: \\ untold stories on disaster and generosity in Grand'Anse, Haiti
}

\author{
Ana Elisa Bersani
}

\section{Introduction}

After a few months of gathering information about what happened in Grand'Anse, Haiti after the 2010 earthquake, I was convinced of the potency and importance of stories I had heard daily from an eclectic group of informants'. The fundamental role played by people in the country's outlying provinces in the rescue of victims and their survival was unquestionable. I was impressed with the extraordinary help ${ }^{2}$ found by these survivors in those places where people and entities quickly and efficiently offered them shelter and relief. However, these stories-part of a larger and poorly visible social process-remained almost inaudible compared to reports of the heroic efforts of professional aid workers and the dramatic suffering of disaster victims.

Much of the existing research on Haiti has focused on the profound difficulties and social constraints of the society. ${ }^{3}$ Since the earthquake, the media continued this trend with biased coverage of existing contemporary social relations and institutions. ${ }^{4}$ Little is known about what happened in provincial towns in the days and months after the earthquake, which were distant from and not the focus of actions of the "international community," major NGOs, and the Haitian state.

Some anthropological work on the aid industry, focused mainly on aspects of economic logic and power relations, has offered severe critiques of the international aid system (Schuller and Morales 2012, Schuller 2012, Farmer 2011). These critiques often emphasize the complexity of humanitarian endeavors and document the topography of power relations. Despite their obvious importance, these analyses tend to obscure the role and perspective of local actors by focusing on foreign agents.

By specifically examining a community-based response (comprising an assemblage of political and religious authorities, local civil society associations, and individual actors), this study demonstrates how these overlooked communities and local actors played a crucial role in disaster management, and became a refuge for thousands of survivors. Through narratives about the disaster from those who lived through it, and by exploring the dynamics and problems involved in a context of disaster and crisis from a different perspective, this article aims to contribute to the broader anthropological literature on humanitarian aid and disaster response.

\footnotetext{
1 The study on which this article is based was conducted between 2012 and 2015. The ethnographic data were taken from my Master's Dissertation “ $O$ (extra) ordinário da ajuda: Histórias não contadas sobre desastre e generosidade na Grand’Anse, Haiti” (Bersani 2015). The research was financially supported by FAPESP. I would like to thank Omar Ribeiro Thomaz for the generosity and the guidance provided during this work. A first draft of this paper was presented at the Latin American Studies Association in May 2015 as part of the panel Eating Together: Food, Materiality, and Sociability in Rural Caribbean. I would like to thank Erica Caple James, Jean-Philippe Belleau, Bette Gebrian, Rodrigo Bulamah and Karen Richman for their critical readings and valuable contributions. I would also like to thank the two anonymous reviewers from Vibrant for their helpful remarks and Jeffrey Hoff for the english review.

2 When referring to "help" in italics, I am pointing to the variety of meanings the term can imply, as it is used to talk about mutual assistance, cooperation, and reciprocal sharing. As an interactive phenomenon and an analytical category, I am also differentiating this practice from that which is carried out by the international aid system.

3 See Trouillot (1990) for a critique of the notion of Haiti's "exceptionalism" and its consequences.

4 According to Schuller and Morales (2012: 2), "throughout the earthquake affected region, the first emergency response came from people themselves... Unfortunately, this wasn't the story that broadcast into people's living rooms across the world. CNN reported the earthquake nonstop for more than a week, capturing the most horrific scenes. It was presented as hell on earth.”
} 
I suggest that crises disrupt ordinary everyday life, and are thus important "time markers," but are paradoxically embedded in a temporal structure of daily experience. The relationship between crisis and improvisation reveals the complexity of social life in which change, crises, ruptures, and instability combine with notions of permanence, integration, and balance. ${ }^{5}$

It is important to draw on the concept of "disaster", within the context of longstanding social processes related to repetitive crises, to understand how Haitian society, despite the scarcity of resources and despair caused by the destruction, dealt with the aftermath of the earthquake. More specifically, the use of a processual approach questions the notion of "help" and aids understanding how people actively involved both in giving and receiving it conceived their own experiences around this concept.

This study investigates collective strategies and modes of help based on a moral economy that mobilized a large variety of organizational structures. More broadly, it explores how this approach contrasts with both the utilitarian and altruistic frameworks. Furthermore, focusing on the perspective of the Haitians themselves about mutual assistance, solidarity, cooperation, and the different ways the concept of "help" (or èd in Haitian Creole) is shaped by their experiences, I examine how in this context, the actions taken to help others may, in fact, not have even been perceived as extraordinary acts.

\section{The event}

Life seems back to normal after decades of turbulence. Young laughing girls hang out in the streets late at night. Crime has stepped back... It is so quiet that some are already worried. We are not used to such a long lull in Portau-Prince. For this young man with his face half hidden by a straw hat, an imminent danger lurks. One wonders what it might be, since we have already seen it all: the hereditary dictatorships, military coups, recurrent hurricanes and blindfold kidnappings (Laferrière, Dany. Déjà La Vie, “Tout bouge autour de moi”. 2010:16). ${ }^{6}$

On January 12, 2010 a dramatic and inexorable event struck the most populated region of Haiti. Port-auPrince, Pétionville, Léogâne, Petit Goâve, Grand-Goâve, and Jacmel were among the cities most devastated by the unexpected and violent earthquake. Aftershocks continued to shake the country's southwest for days. Within seconds, communication and transportation systems ceased working and electrical grids were severely damaged. Homes, hospitals, schools, and countless other buildings collapsed. According to official estimates some 230,000 people died, over 300,000 were injured, 1.3 million displaced, and 1.5 million left homeless. The cemeteries were quickly overcrowded, and within a few days 80,000 bodies had been buried in mass graves. Thousands more were burned or buried by relatives on their own private land.7

\footnotetext{
5 Several authors have addressed the issue of temporality in relation to critical events. This subject will be dealt with more deeply later in this work. As references see, for example, Das (1995), Bessin, Bidard and Grossetti (2010) and Bensa and Fassin (2002). More specifically on the notion of crisis in Haiti, see Greg Beckett (2019).

6 Author's translation from the original text in French: "La vie semble reprendre son cours normal après des décennies de turbulence. Des jeunes filles rieuses se promènent dans les rues, tard le soir. Le banditisme aurait reculé d'un pas... C'est si calme que certains s'inquiètent déjà. On n’a pas l'habitude d'une si longue accalmie à Port-au-Prince. Pour ce jeune homme au visage à moitié caché par un chapeau de paille, un danger imminent nous guette. On se demande ce que cela peut être, puisqu'on a déjà tout connu : les dictatures héréditaires, les coups d'État militaires, les cyclones à répétition et les kidnappings à l'aveuglette." (Laferrière 2010: 16)

7 All data regarding the number of victims are government estimates released shortly after the earthquake without any effort to identify bodies buried in mass graves.
} 
Within Port-au-Prince - the political, institutional and economic center of the country - the losses were incalculable. Thousands of buildings were destroyed or seriously damaged, including some of the most important cultural and governmental buildings in the capital. The presidential palace, parliament building, ministries, the Notre-Dame de Port-au-Prince, the Holy Trinity church, the main prison, and all of the city's hospitals were devastated. Universities and schools had to cease all of their activities during the aftermath and recovery. It is estimated that $10 \%$ of the city's population died. ${ }^{8}$

Photos of the disaster spread quickly over the Internet and on news media. International coverage of the tragedy was non-stop, and numerous countries pledged support in the form of funds, equipment, food, medicine, rescue operations, medical teams, and engineers. Major international institutions staged a real "humanitarian show." As Mark Schuller noted, "Haiti's earthquake thrust the international aid system, particularly NGOs, into the public spotlight" (2012: 6). Despite the media focus on the international response, international aid was often ineffective in reaching the most afflicted (Schuller 2012, Podur 2012, Thomaz 2010, 2011). As Beverly Bell affirmed, "in Haiti, the disaster aid was an aid disaster" (2013: 77).

Medicine, food, blankets, and water arrived at the airport, but remained there rather than being distributed to Haitians in need. 9 Aid workers trained in emergency response were sent to the scene but could not work because of alleged violence in the streets. Instead, they stayed at the airport awaiting implementation of a plan that would guarantee their security. As portrayed in Raoul Peck's documentary, Assistance Mortelle (2013), the primary cause of the ineffectiveness of the humanitarian intervention was the distance between the international organizations and Haitian civil society. Due to the superficiality of this relationship, already existing efficient distribution channels were not utilized. ${ }^{10}$

Exposure of these problems sparked a discourse critical of the humanitarian response not only among aid workers and journalists (Katz 2013), but also among anthropologists who entered the debate. Due to the huge aid apparatus that became engaged in the days following the quake, particularly in Port-au-Prince, it was hard to ignore the abuses, inequalities, failures, and injustices committed in the name of aid and assistance. A range of critical analyses has appeared focusing on the aid system and its political partiality. In an effort to reveal "how power operates, and the roles our development aid and agencies administering that aid play in transforming local civic life" (Schuller 2012: 8), analyses focused on the international apparatus. Haitians were consistently viewed only as victims either of the earthquake, or of the well-intentioned organizations. Analysis of the role of foreign agents (governments, companies, and others) is clearly important but has tended to obscure the important role of local actors. I argue that national agents played a central role in the emergency response, and were not just victims.

\footnotetext{
8 It is estimated that the Port au Prince region had a population of 2 to 3 million people at the time of the 2010 disaster. However, as noted before, since the last population census was taken in Haiti in 2003, the demographics are not accurate.

9 According to Justin Podur, "the U.S. military took over the Port-au-Prince airport on January 13 and immediately gave priority to its own military flights, turning away World Food Program flights, medical supplies from Doctors Without Borders, including an inflatable surgical hospital on January 16" (2012: 139). The BBC correspondent in Port au Prince, Mathew Price, also reported that there was "little sign that humanitarian aid was leaving the airport in the Haitian capital.” http://www.bbc.co.uk/portuguese/noticias/2010/01/100114_haiti_ajuda_vale_np.shtml, accessed on June 23 rd, 2011.

10 Thomaz (2010, 2011) observed that the basis for this superficiality was a relationship between international aid workers and Haitians marked by ignorance and fear. He argued that foreigners often have minimal contact with the population and local culture, mostly depending on brokers of one form or another. They can rarely speak or understand Creole, the only language spoken and understood effectively by all Haitians. Ignorance and fear form the basis of a relationship that keeps Haitians apart from the decision-making process regulated by the international organizations. There was no interest in establishing more effective communication with the population. The only interest they had was to give orders or directions that would lead the locals to "development." This divide was easily observed by the widespread feeling of contempt that Haitians demonstrated towards the MINUSTAH (United Nations Stabilization Mission in Haiti) soldiers in the country between 2004 and 2017, for example. Demonstrations calling for MINUSTAH's departure were widely supported during my stay in 2013.
} 
Given the inadequacy of the "aid industry" (Escobar 1996), and despite the scarcity of resources and the despair caused by the destruction, Haitians organized themselves to distribute food and water, and any money left in their pockets without hesitation. Amidst natural chaos and institutional breakdown, there was still a place for help since the lack of state leadership did not prevent the organization of the population (Bell 2013). Through so-called traditional institutions and informal markets, these civilian sectors were the only entities capable of responding to the disaster with the necessary immediacy. ${ }^{11}$

The media often reported on the lack of security and control, focusing on the disorder, fear, and looting. The tragic experience of those days was summarized in reports that spoke only of violence, as the world watched scenes of widespread chaos in astonishment. News reports blamed the fragile Haitian state apparatus for the obstacles to mobilizing an adequate aid response. ${ }^{12}$ Some even affirmed that the country's culture and the widespread practice of Vodou had a role in causing the tragedy. ${ }^{13}$

In the days following the quake, thousands of people-usually wealthier individuals with passports and visas-managed to leave the country to stay with relatives or friends in the Dominican Republic, the United States, Canada, or France. Some 6oo, ooo others also left the capital region for provincial cities, seeking asylum at relatives' or friends' homes. Those individuals in the provinces-who once depended on remittances from family members working in the capital-offered great help to survivors despite their own struggles and difficult living situations.

\section{The Response}

After the earthquake struck, some 500,00o people left Port-au-Prince to seek refuge in the provincial cities. They departed for the peasant areas with empty hands, without any money or state or NGO aid. The peasants welcomed all these people, gave them places to sleep, food, and all kinds of aid... There has been no evaluation of the amount of money, sacrifice, and infinite solidarity that the peasants paid out. (Chenet 2012: 99)

Amidst the ongoing aftershocks in the days following the earthquake, survivors traveled throughout the country in search of assistance. The Grand'Anse department received the second highest number of refugees (see Figure 1).

\footnotetext{
11 It is important to highlight that the term informal should not only be understood as a category defined in opposition to the formal state sphere. Considering the complexity of informal activities and their relations with other social spheres-which have their own set of rules and norms-informality should not be associated with the idea of an unruly and illegal space.

12 Throughout the country's history, the Haitian state has largely failed, if we consider the idea of modern state. However, the state's limited capacity to provide basic social services related to social welfare does not indicate a complete absence of the state's presence.

13 In her essay “From Slave Revolt to a Blood Pact with Satan: The Evangelical Rewriting of Haitian History," Elizabeth McAlister discussed the implicit questions raised when on the day immediately after the earthquake, television evangelist Pat Robertson, while hosting his new talk show The 7oo Club, on the Christian Broadcast Network, said that the earthquake could be best understood by a little-known event that "people might not want to talk about," Haitians were cursed, he said, because they long ago "swore a pact to the devil" (2012: 203). Another more polite version of this argument can be found in David Brooks' article "The Underlying Tragedy" published January 14, 2010 in the New York Times. He accuses Haiti of having "progress-resistant cultural influences," including "the influence of the voodoo religion." In both examples, to some extent Haitians themselves are blamed for having caused the tragedy.
} 
Figure 1: Population Movements out of Port-au-Prince (Source: OCHA - 1 March 2010).

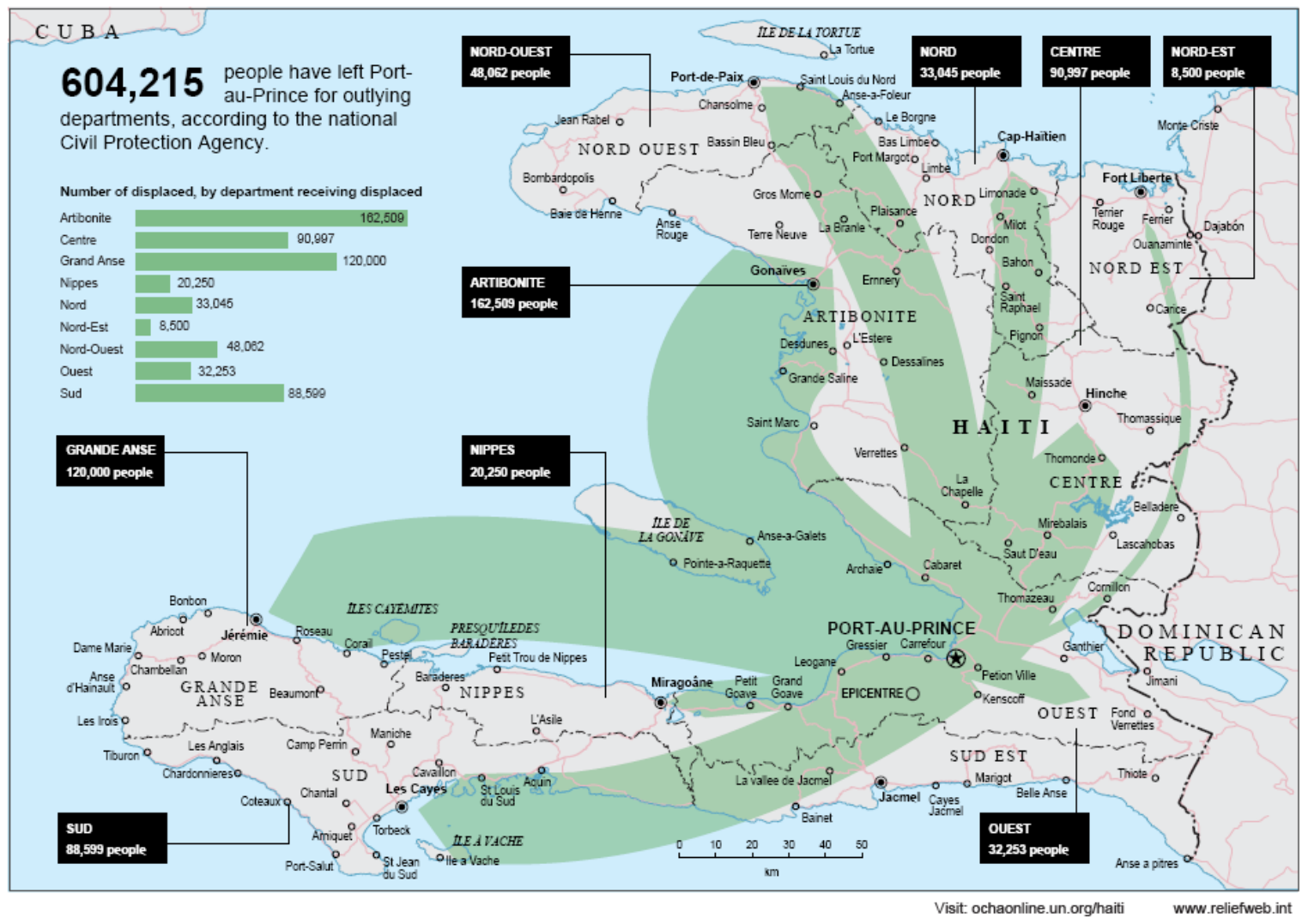

In the town of Jérémie, the provincial capital, the response began a few hours after the first news of the earthquake. Tremors were felt in all 12 communes but caused little overt physical damage. Some public buildings had cracks, including the Saint-Louis church in downtown Jérémie, the Jehovah's Witnesses church and the Catholic Church of Corail. According to information collected by local authorities and reported by the Department of Risk Management and Disaster Coordination in Grand'Anse (DGCA/GRD), the earthquake caused 9 deaths and left 15 injured in Grand'Anse.

Despite the limited initial physical impact in the region, most everyone in Grand'Anse was affected in some way. In contrast to the bureaucratic categorization that only considered the region of Port-au-Prince to be affected, residents of Grand'Anse can also be considered direct or indirect victims of the tragedy. Most families had at least one member living, studying, or working in Port-au-Prince at the time of the earthquake. Even among those few who did not have close family members in Port-au-Prince, there was still much concern about friends living there. The stress in the immediate aftermath was aggravated by the lack of communication, given that facilities and antennas of telephone companies were damaged. The few people who did receive calls would communicate news to others as soon as possible through local radio stations, which played a crucial role in communication and community mobilization.

Debris and large stones blocked the road between Port-au-Prince and Grand'Anse, preventing the passage of cars, especially in Léogane and Petit-Goâve. Mass transportation and private cars could not pass. Boat service was suspended indefinitely. Rumors spread about the risk of a tsunami, adding to the fear of an already shaken public. Public institutions were completely paralyzed because of the destruction of state buildings in the capital and a lack of communication between the different levels of government. 
Despite the barriers and lack of resources, civilians in Jérémie organized, devised, and executed strategies to rescue survivors in Port-au-Prince and offer them asylum in Grand'Anse. The former president of the Civil Society Association of Grand'Anse (Société Civile Organisée de la Grand'Anse - SOCOGA), François Cheyner Dépeine, along with other members of the association, called a meeting with a variety of individuals and institutions from several sectors of society. This meeting was held on January 17, 2010 at the city's Catholic diocesan offices, with the participation of local NGOs and civil society organizations, including CARE, CARITAS, the Haitian Health Foundation, Médecins du Monde; priests and other religious leaders; deans of colleges and technical and professional schools; as well as heads of public offices such as the Department of Public Safety and the Ministry of Women's Protection. Together, they created a Comité d'Urgence (an emergency committee) to join forces and face the challenges.

The first task of the Comité was to convince the owner of the Trois Rivières boat to make trips to rescue survivors in Port-au-Prince. It was agreed that the passengers would not be charged for transport. Several fundraisers were organized to purchase the required fuel. These marathons were run by local radio DJs who asked people for donations of food, clothing, and money. The Trois Rivières completed its first trip after the earthquake on January 25, arriving in Jérémie at 3:30pm with 3,200 people on board. Many other trips were made in the following days, and it is estimated that by January 27 , over 80,750 people safely arrived to the Grand'Anse and were registered by the committee and municipal authorities. ${ }^{14}$

Upon reaching the wharf in Jérémie, earthquake survivors were greeted by employees of various organizations, citizen volunteers, and members of the Comité d'Urgence. After an initial screening, injured people were identified and those in need of immediate help were directly referred to the Hospital Saint Antoine. Pregnant women were sent to the Hospital Centre L'espoir (the Haitian Health Foundation's maternity clinic). Many people arrived with serious injuries that had not been treated in Port-au-Prince. The role of youth, especially nursing students because of their expertise, was crucial at this moment and should be highlighted. Food, clothes and water were distributed immediately. Trucks and buses were made available by their owners to bring the newcomers as close as possible to their destination communities.

The migration from Port-au-Prince to Grand'Anse lasted several months. Those who didn't have the chance to make the crossing aboard the Trois Rivières went by foot, truck, or small sailboat, and many people used a combination of these modes of transportation. They often made their way to their hometowns without being able to communicate ahead, sometimes showing up unannounced in the middle of the night. Relatives, friends, or volunteers shared their modest homes to accommodate them. Remarkably, it was not necessary to erect tent cities or create refugee camps. When survivors arrived, locals greeted them with astonishing generosity, provided them food, and took responsibility for their needs.

14 According to the official report sent by the Emergency Committee on January 28th, 2010. 


\section{The Refuge}

Figure 2: Political and Administrative Map of Haiti (Source: Nations Online Project, accessed in 2013)



The department of Grand'Anse, which means Great Bay in English, occupies the northern part of Haiti's southern peninsula (see Figure 2), and was only officially established in 1962, when it was separated from the Sud department. ${ }^{15}$ In 2003, the new department of Nippes was formed out of a portion of Grand'Anse. Grand'Anse now has 12 municipalities (communes), ${ }^{16}$ in three arrondissements: Anse d'Hainault, Corail, and Jérémie. With a population of approximately 446,000 inhabitants, ${ }^{17}$ this mountainous region contains some of the country's last remaining heavily forested areas.

When, in early February 2013, I left Port-au-Prince for Jérémie, these were some of the few things I knew about the place where I would spend the next four months, the largest city and capital of Grand'Anse, with about 35,000 inhabitants. ${ }^{18}$ I took a bus that was supposed to depart at 8am accompanied by a Haitian friend who insisted that I should not travel alone. He was going to Jérémie to visit his family, including his sick father, who died shortly after our arrival. After two hours of waiting and several unexpected mishaps we began a long and arduous

15 The area was first named by the French in 1673 in reference to the large opening offered by the bay (Dorimain 1978: 10).

165 The 12 municipalities (communes), including 9 on the coast, in the department of Grand'Anse are: Jérémie, Abricots, Bonbon, Chambellan and Moron (district of Jérémie); Corail, Beaumont, Pestel and Roseaux (district of Corail); Anse-d'Hainault, Dame-Marie and Les Irois (district of Anse-d'Hainault). According to the administrative organization of the country, the municipalities are further divided internally by rural sections (sections rurales), which are composed of villages or neighborhoods. The smallest administrative unit is called an abitasyon, and roughly correspond to colonial holdings or topographical landmarks.

17 'Since Haiti's last census was in 2003, demographic data is not considered accurate. Quantitative analyses are based on inaccurate estimates and projections made in 2009 and 2012 by IHSI - Institut Haitien de Statistique et D'informatique.

18 March 2009, Institut Haitien de Statistique et D'informatique - IHSI. 
journey. ${ }^{19}$ It took 12 hours to travel the 180 miles on the only road connecting Grand'Anse to the country's capital. Excited by the challenges of ethnographic fieldwork, I finally arrived at the location I had chosen to be my "field", a place that served as a refuge for more than 200,000 Haitians after the earthquake in 2010. ${ }^{20}$

The bus traveled down the road spewing white dust while dodging and narrowly avoiding obstacles, to which the driver and passengers reacted nonchalantly. As we rattled down the crooked road, which was paved only as far as Les Cayes (the capital of the South department), the landscape slowly changed. Rugged white cliffs gave way to splendid green vegetation that stretched endlessly before us as we climbed slowly through the mountains. We were now in Grand'Anse.

The bus proceeded along the edges of the cliffs, and the increasingly obvious risk contrasted with the calm of the river running through the valleys below. One of the four rivers that crisscross the peninsula ${ }^{21}$ shares its name with the department itself. It is still used to transport products and goods from rural areas to the city on market days, on bamboo rafts called "piperettes". These rivers are also used for personal hygiene, irrigation, drinking water, and washing clothes and vehicles. Before reaching the sign that announced our arrival with the words "Welcome to Jérémie" in both French and Haitian Creole, it was necessary to cross three more steel and concrete bridges. ${ }^{22}$

One can also reach the Grand'Anse on an expensive daily flight from Port-au-Prince that takes only 50 minutes, or by a 12-hour boat trip that may take days depending on the weather and the condition of the boat. Travel between the "communes" (municipalities) and towns within the department is even more difficult. Many areas are almost impossible to access by car due to the lack of paved roads on the steep hillsides, as well as impassable rivers. Many people must travel by foot. It is evident that the forests and woodlands here have been preserved from the devastation that ravaged other parts of the country over the last two decades. Much of this preservation can be attributed to the lack of access that makes Grand'Anse one of the most geographically rugged and remote regions of Haiti. ${ }^{23}$

These geographic and topographic features suggest separateness and isolation but do not constitute insurmountable barriers to access and communication in a globally interconnected world. People routinely react creatively and dynamically when confronting these geographic barriers, to avoid stagnation. Anthropologists commonly observe social and economic processes that connect even the most isolated regions with a wider world. However, the peculiar spatial experience of Grand'Anse and Jérémie associate them to a neglect, remoteness, and distance that should be carefully reconsidered. To remain sensitive to the role of spaces and their effects on lived experience and people's worldview is not the same as adopting a deterministic approach that simplistically characterizes locally lived existence.

19 The bus in which we should have made the trip had to be replaced because it was in an accident, but this justification did not convince some passengers who protested and refused to embark. According to these passengers, the first bus, in better condition, was being used to serve tourists who were going to the carnival in the city of Jacmel.

20 In March 2010, the United Nations Office for the Coordination of Humanitarian Affairs - (OCHA) released a map illustrating this population shift to other departments in the country (see Figure 1). An estimated 162,00o migrants left for the Artibonite department, and 120,000 for Grand'Anse - around 20,000 of whom went to Jérémie. However, this illustration is based on estimates provided by the Haitian government, relying solely on officially reported data. Thus, it vastly underestimates the actual number of migrants since it does not include the many people who traveled by boats, buses, trucks, or who even walked.

$21{ }^{10}$ The Voldrogue, Grand'Anse, Guinaudée, and Roseaux rivers.

$22{ }^{11}$ The bridge that crosses the Grand'Anse River in Jérémie was built in the 1940s during the administration of President Dumarsais Estimé to replace an old metal drawbridge built by Doret that had been completely destroyed during a large flood in 1935 (Cavé 2010). Until 1987, when a development project funded by France for the construction of bridges began, rivers were crossed only on foot or by car, and were often impassible during the rainy season.

23 The ecological crisis of the past two decades in Haiti was largely caused by economic embargos that made vegetable charcoal the only energy source available to most Haitians. This led to a process of deforestation that has worsened, leaving more than 98 percent of the country deforested (Hunter 1996-97: 609 ) and negatively impacting the population's food security. Although Grand'Anse is one of the last areas to maintain substantial forest reserves, such as Macaya National Park, deforestation is increasing at an alarming rate, mostly to supply demand for charcoal. The Port of Jérémie (Wàf Jérémie) ships thousands of bags of charcoal per week to Port-au-Prince and other regions of the country. Haiti's deforestation began during its colonization, which created a destructive plantation system that exhausted the soil through excessive sugarcane harvesting. Large areas of forests were overtaken by new settlements and exhausted by the export of valuable lumber to Europe. This destruction continued after Haiti's independence as a result of a wide variety of agricultural and industrial pursuits, and by the Haitian people's search for fuel. See Dubois (2012: 4, 20), Smith (2001: 70), Faber (1993) and Tarter (2015) for more details. 
By emphasizing processes and practices of "place making", Akhil Gupta and James Ferguson argue that "all associations of place, people, and culture are social and historical creations to be explained, not given natural facts" (1997:4). To better understand the processes through which a specific space achieves a distinctive identity as a place, one must focus on how this perception of locality was discursively and historically constructed (Low 2009). From this perspective, the idea of isolation associated with the region and considered by this work is not taken as a given fact, but is instead considered a complex and contingent result of ongoing historical and political processes.

During the nineteenth century, international trade was very important in Jérémie. Ships carrying indigo, coffee, cocoa, sisal, and rum left the harbor, which was opened in 1807 , for a variety of global markets. ${ }^{24}$ During the nineteenth and twentieth centuries Jérémie had consulates representing the governments of Brazil, Germany, France, the United States and the Dominican Republic (Gebrian 1993). The town had a very active social scene and was known as the city of poets, artists, and philosophers. ${ }^{25}$ It was reputed for its intellectual residents who went not to Port-au-Prince, but to Paris for their studies. Jérémie came to be called the "Paris d'Haiti" (the Paris of Haiti), and its culture and architectural style were compared to that of the French capital according to the biographic writings of Rose Marie Perrier (1993: 51).

During the second half of the twentieth century however, the city's distinction declined and its connections to the "rest of the world" weakened (Perrier 1993, Cavé 2010, Alcindor 2011). Direct trade with other countries was suspended in 1950 as steamboats replaced sailboats, and the city's pier was unsuitable to accommodate these new vessels (Gebrian 1993). Soon after, then President François Duvalier banned foreign ships from docking in any Haitian port other than Port-au-Prince.

The resulting decline in trade intensified deterioration of Jérémie's physical structures. The few factories were closed, and their owners abandoned the region. Another important event was the massacre of 27 mulâtres ${ }^{26}$ from two families who were members of the economic and cultural elite of Jérémie, an act instigated by the Duvalier government in $1964 .{ }^{27}$ The tragedy, known as the "Vêpres jérémiennes," marked Haitian history and is often associated to the region's decline, as many of the more educated residents subsequently left Jérémie for the United States and Europe (Gebrian 1993: 77).

Narratives about the region often alluded to a feeling of desolation, emptiness, and abandonment that characterized the provinces at the time, and have significantly informed Grand'Anse's identity until today. In the first few days after my arrival in Haiti, while I was still in Port-au-Prince, Haitians consistently expressed surprise when I said I would be moving to Jérémie. They promptly revealed concern with my intent to conduct research in the region. Most thought it a strange choice precisely because of its remoteness. This widespread sentiment towards Grand'Anse became increasingly evident.

\footnotetext{
$24{ }^{13}$ The region also has a special connection with Jamaica (about 160 miles away). The short distance by sea between the two coasts facilitated a British invasion in September 1793. British forces from Jamaica occupied parts of the western and southern provinces of Saint Domingue for five years. Remnants of old forts are still found in Marfranc, 30 minutes from Jérémie (Gebrian 1993: 76).

25 Included among the most famous were Alexandre Dumas and Émile Roumer.

26 Mulâtre is the term use for those born to one white and one black parent, or to two mulatto parents. Racial prejudices that privileged light-skinned Haitians, benefitted them with an extraordinary position of strength.

$27{ }^{16}$ Although the event is widely known due to the extreme brutality, it is rarely discussed and is usually treated as "taboo." This silence leaves many questions, and it is difficult to find accurate information in written sources. During my research, references to the massacre were rare, and apart from Chassagne's (1977) record, most of them are accompanied by an attempt to justify the crime by referring to the alleged discrimination practiced by the mulâtres against black people. This practice of removing mulatre elites from power was promoted by the noirisme, especially during the 1930s and 40 . For more on noirisme, see Dash (1981), Hurbon (1993), Midy (1993), and Smith (2004, 2009).
} 
On a political level, it is also well known that politicians in Port-au-Prince do not distribute resources equitably, so they rarely reach outlying areas of the country. ${ }^{28}$ The anthropologist Jennie M. Smith, who also conducted fieldwork in, described the region as being "more neglected than most other departments in terms of infrastructure" (2001: 13). Public services for the population are almost nonexistent. Electricity, water and septic systems are privileges of an elite minority, state offices, headquarters of international organizations, or Christian missions. Local politicians often establish residence in the national capital, and return only sporadically to Grand'Anse to communicate with constituents.

Much of the resources and products that currently supply the city are transported from the mountainous areas in the interior of the department on the backs of mules, or on the heads of rural farmers (peyizan) who walk on unpaved roads that deteriorate each rainy season. Every Friday, after a week of anxious waiting and anticipation, a boat laden with products and passengers arrives from Port-au-Prince. Jérémie's port (Wàf) becomes a large open-air market where people finally gain access to manufactured or imported goods. It is the only day of the week they can cook with cheese, for example, one of many scarce commodities in a city where there is no steady supply of electricity for refrigeration.

Interestingly, the tale of the founding of Jérémie provides a lucid metaphor that is helpful in illustrating the multiple dimensions of its "isolation." It is said that in 1756, fishermen living just east of Jérémie (in a small settlement called Vieux-Bourg) moved west for protection from storms and hurricanes. They settled in an area that was already the home of a fisherman named Jérémi, and therefore named it Trou Jérémie, or in English, "Jérémie's hole" (Dorimain 1978:13, Perrier 1993:47, Saint Mercy 1982 [1797]). Originally, the name of the city kept the word trou which means "hole" in both French and Haitian Creole. While "hole" refers to the idea of confinement, a lack of horizon, an empty space, solitude, and remoteness, it is also in a hole where one can hide from danger and find shelter, asylum, protection, and security.

The boundary between these two aspects of isolation is not always clear, and their arrangements are shaped by the experience of actors who deal with the multiple facets of this "isolation" on a daily basis. When I first arrived in Grand'Anse, I did not know that it was one of the most important sites for the practice of marronage ${ }^{29}$ during the revolution that led to the country's independence in 1804. Plymouth and Macaya, two famous leaders who organized the struggle against the colonialists in the West, took refuge in the high mountains of Grand'Anse (Dorimain 1978), which now bear their names..$^{30}$ There, the persecuted were able to evade danger. In 2010, thousands of earthquake survivors fled to these very same mountains, all in search of what we might call a safe place, or a refuge.

\footnotetext{
28 During the US occupation (1915-1934), a development model was established that led to urbanization and concentration of resources in Port-au-Prince. Tax revenue was centralized in Port-au-Prince without being redistributed to the provinces. The consequences of this period are felt to this day and help understand the ever-increasing flow of people who migrated to the capital (Alcindor 2011).

$29{ }^{18}$ Marronage refers to an organized way to escape from slave labor and plantation life, which allowed groups of slaves to flee with the assistance of other fugitive slaves. Mawon is the word in Haitian Creole for "runaway slave," originally from the Spanish word Cimarron that means "living on mountaintops." African slaves who fled to remote mountainous areas of Haiti were called mawon, where they formed cohesive communities that practiced small-scale agriculture and hunting. See also Debbash, 1961, 1962.

30 Pic Macaya is 7,700 feet in altitude, and the second tallest mountain in Haiti.
} 


\section{Yonn ede lòt}

The specific condition of this region and its strong connection with the experience of isolation led to the establishment of well-articulated mutual assistance networks, which are extremely active and capable of mobilizing multiple actors in different sectors of Haitian society. This social dynamic made possible the organization of an immediate and extremely efficient response within the context of insecurity and crisis. This complex web of relationships not only allowed accommodating survivors, but was also responsible for the organization of production and circulation networks that were decisive to ensuring food and other supplies to the communities.

The help performed as an emergency response employed various strategies of labor and resource sharing that figured already as daily practices used by the communities to cope with hardship. During my stay in Grand'Anse, I witnessed how the longstanding tradition of yonn ede lòt (Haitian creole for one helping the other) was intricately intertwined to daily routines. People regularly called upon each other and came to assist one another. Houses rarely consist of only nuclear family members, but often host a variety of extended family and non-kin. Neighbors, in this context, are deeply involved in a gift dynamic, which inserts them into a network of benefits and obligations. The subject and object of help exercises what we could call a tyranny of affection.

It is important to note that when I refer to the Haitian expression Yonn ede lòt, I am referring to a myriad of practices that are not exclusive to the rural universe. They must not be considered through a simple and minimalist perspective in which the Haitian peasantry appears to be idealized and romanticized, representing a past that remains isolated, untouched, and pure.

Within this dichotomous scheme, close to a Rousseauean logic model, Haiti's rural universe is often described as a representation of the past, while the city embodies the future. The tension between country and city-although understood in various manners - is indeed a fundamental myth of modern social thought. This has eventually polarized dominant concepts between two main alternatives: the rural universe-replete with traditions, harmony, morality, and dignity; and urban reality-cramped by crowds and the crush of the individual. In contrast to this approach, Sidney Mintz' works were essential to refuting an urban-rural polarity, emphasizing the connections established between these spaces in a continuous process of transformation.

The prioritization of collective labor can be seen in a variety of groups that organized to share labor, especially in rural areas. The most popular collective labor arrangements in Grand'Anse are called eskwad, ${ }^{31}$ but there are a variety of more complex arrangements, generally referred to as konbit or kòve, ${ }^{32}$ which have been studied and described extensively by anthropologists. In her book When the Hands Are Many, Jennie M. Smith (2001) richly describes the collective practices of agricultural labor along with grass-roots organization and cooperative traditions, helping us to understand the extensive, already existing Haitian commitment to sharing labor and resources that goes well beyond pragmatic interests.

Smith describes the ways peasants in Grand'Anse work together and share resources. Evoking Bourdieu's notion of "habitus", she notes: "More deep-seated than an ethical principle, yonn ede lòt... is an embodied understanding of how one must dispose oneself vis-à-vis others" (2001: 75). The help offered as an emergency response in Grand'Anse was extraordinary in that the province received and accommodated more than 200,000 people, and was to some extent even more efficient than the development and humanitarian aid apparatuses. At the same time, the strategies and practices performed by civilians and households to help the survivors after the quake were completely ordinary from their own perspective, since interdependence, cooperation, and reciprocal sharing are fundamental to their day-to-day tasks.

\footnotetext{
31 Small groups of neighbors and kin who agree to work in one another's fields for a few hours, several days a week. Money is generally not involved in these labor exchanges.

32 For a detailed description of the konbit and kòve practices in Grand'Anse, see Smith (2001: 83-88). For a broader discussion, see also Lundahl (1983); Herskovitz (2007 [1937]); Mintz (1961) and Bulamah (2013).
} 
People are inextricably interconnected, and therefore dependent on one another. Common expressions like "Yon sèl dwèt pa manje kalalou" (one finger on its own can't eat stew), or "Men anpil chay pa lou" (many hands lighten the load) illustrate well this fundamental aspect of Haitian social life in which mutual support is also a survival strategy. This framework shows us how Haitians consider mutual assistance to be an ordinary practice of sharing connected to the exercise of citizenship and broader forms of belonging, in contrast to the framework applied by the humanitarian aid system. Evidently, these relational obligations are not free from constraints, and can often pose a threat to an individual. Although they are often associated with the principles of blessing and care, they can also cause suffering and discomfort, and are even related to (and do not exclude) witchcraft practices and magical threats.

The reorganization of the Haitian population following the tragedy in 2010 gave rise to new challenges that needed to be solved to ensure the maintenance of order and the survival of the displaced. The story I tell here evokes Mauss's notion of "gift" (1991) since it appears to be an exchange based on a general sense of belonging that is not reduced to market principles or utilitarian calculations. The Gift does not evoke generosity in a religious sense, as illustrated by the image of the Good Samaritan, since it is not completely altruistic. ${ }^{33}$

Through their generosity, people earn distinction and respectability. Despite of that, self-interest does not determine the relationship upon which it is based, especially considering belief in the value of social ties. These social ties are established through relationships of mutual trust among members of a community who commit to a cycle of gifts. This is only achieved through a balance between spontaneity and obligation, between freedom and responsibility. As I mentioned, these relational obligations are not free from constraints, and can also be the cause of suffering. The polar opposition of self-interest and altruism is not a useful framework here since it poses a false dichotomy. Thus, the voluntary characteristic, apparently free and volitional, is actually obligatory and self-interested at the same time.

Power is also diluted here since those offering help also feel they are victims, and thus they act with a feeling of shared responsibility. The strength of the social tie rests in the fact that it is more than a junction of particular interests. The Gift (Mauss 1991) is not only derived from the relationship, but constitutes the relationship itself. Giving is not just contingent upon preexisting relationships or confirming social ties, but is also an ongoing process in which these relationships are forged.

As Bell (2013: 51-52) suggests, the community-based help that was mobilized in response to the earthquake was characterized primarily by three elements:

First, no one ultimately has more than she or he started with, but the sharing allows each to do more with meager resources than would otherwise be possible. Second, unlike micro-credit, which demands interest (sometimes for program costs and sometimes for profit), in these systems no one takes any fees or makes money off anyone else. Third, the exchanges are based in human relationship and trust.

I did not directly witness the events immediately following the earthquake, as I arrived in Haiti three years after the catastrophe. Likewise, my impressions were not based on my own subjective personal experience of the event. From the beginning, my information came through narratives about the disaster told by those who lived through it. My sources were the memories ${ }^{34}$ of those who experienced the disaster, and the devastating effects it caused that continue to manifest and evolve over time. When asking others about their experiences for

33 Here I am referring to the idea of "Agape," where the gift is situated in a scheme of specific action: one of love, as described by Boltanski (199o). The voluntary aspect of love, according to the notion of "Agape," is characterized by the idea of giving to the other without an expectation of reciprocity. Particularly interesting is the work published in La Revue du M.A.U.S.S from 1981 onwards by a group of French intellectuals. See the number 32, "L'amour des autres: Care, compassion et humanitaire" (2008).

34 There is a wide and interesting discussion about memory, available in a specialized anthropological literature that problematizes this element as a source for reconstructing and analyzing events. Although not used in this text, this discussion is extremely relevant to this study that seeks to value and give relevance to local perspectives. For more details on this discussion see, for example Halbwachs (1990), Bosi (1979) and Pollak (1986). 
the purpose of my research, I often felt an overwhelming sense of embarrassment, because I was asking about memories that are often too painful to be relived. At the same time, I found myself quite perplexed because I was expecting to hear dark emotional stories about trauma and suffering, but instead encountered individuals who did not understand suffering, hardship, and sacrifice as elements of an extraordinary condition.

Antoine's family, the third I visited in Carcasse, a coastal community at the southern tip of the peninsula, took in ten people, including children and grandchildren, in a small three-room house for two years. The household came to total eighteen residents in a small dwelling during this period, and they sustained themselves from the garden next to the house and Antoine's fishing. In Sasye, a small community in the Jérémie mountainous region, I met Ti Frè's family, which included himself and two children living in a house with two rooms. The family hosted twenty-four people, of whom only five were close relatives. These earthquake survivors arrived only a week after the disaster without any prior notice and stayed for a whole year. Ti Frè, a farmer, was the main provider for all 24 people.

I scoured the three arrondissements of the department, talking to host families that received people displaced by the earthquake, collecting their stories. Even in the most remote corners, one could find objective examples of community solidarity. Convinced of the considerable constraints those humble families faced to offer help to the new arrivals, I always asked the same question: "how did you perform such a feat?" And every time, from each family interviewed, I heard a variation of the same answer, given without any fanfare: "Nou te degaje n." The expression in Haitian Creole for "we managed to do it." Looking for the best way to express this idea in English, I came across the expression "we fended for ourselves." This also carries an interesting connotation since it has the meaning of care and doing the best possible despite limitations.

The consequences of the tragedy, especially the redistribution of the Haitian population, led to difficulties that have been largely addressed by a unique social dynamic through which reconfigured networks of relationships both between country and city, and beyond Haiti's borders, maintained order and the survival of victims. Among the institutions that were essential to the survival of Haitians after the disaster are, for example, family relations, fosterage or folk adoption, neighborhood relations, and friendship. ${ }^{35}$ Often unmentioned, these mechanisms, which go beyond the reach of state institutions and sophisticated international resources, have been extremely effective.

\section{Final remarks: About disaster and help}

In scientific terms, an earthquake is a phenomenon of sudden and transient vibration of the earth's surface as a result of the underground movement of tectonic plates. This movement is caused by the rapid release of large amounts of energy in the form of seismic waves. These "natural disasters" occur at the boundaries between tectonic plates or faults between two boulders. We know that the island of Santo Domingo is an active earthquake zone because it is located exactly over a fault system called the Enriquillo-Plantain Garden fault zone. On January 12, 2010, a "natural disaster" shook Haiti, thus proving the real dangers of this phenomenon.

The term "natural disaster" evokes a scientific discourse that links the event to its natural causes and emphasizes the idea of danger. This line of thinking often fails to understand the process by which the event continues to expand temporally (Revet 2018). Thus, the term "post-earthquake" should not suggest that a particular moment was surpassed, but rather should refer to a period that seems to drag on until the present.

35 The centrality of family relations, integrated to friendship and neighborhood relations, is examined in classic works on this country, such as Herskovits (1937), Bastien (1951), Métraux (1951) and Mintz (1971), and also in more recent studies, such as Lowenthal (1987), Marcelin (1988), Woodson (1990), Bulamah (2013) and Dalmaso (2009, 2018). In 1928, Jean Price-Mars also wrote beautifully about the Haitian rural family. 
Considering only the events of January 12, 2010 in the vicinity of Port-au-Prince, the event is set exclusively in a temporally and spatially restricted framework. It is located at a fixed point in the past through the idea of a unique, uniform and linear time (Agamben 2005).

There is a trace of exceptionality that characterizes the event and gives it a sense of disjunction, an interruption of the normal flow of time and everyday experience. Even if the disaster is considered an historical event of deep and dramatic rupture, the phenomena triggered by it should not be considered individually, since they are closely related to long-term social processes. The procedural approach advocated by Sorokin (1942) suggests grasping the concept of "disaster" as a type of crisis that occurs in a social time - which is not just chronological, and involves cultural, political, economic, and subjective dimensions. A catastrophe is thus considered within the broader framework of a socio-historical process, and therefore not merely as natural, but as a socially constructed phenomenon.

Susanna Hoffman and Anthony Oliver-Smith (2001) also describe the concept of "disaster" as something that extends temporally, and includes the immediate facts (the accident itself) and their consequences within the same process. A critical event (Das 1995) does not end at the time of its occurrence but endures necessarily through language and memory. In the same way, the victims' experiences of pain and suffering cannot be objectified and contained within a defined territory (Camargo da Silva 2005).

Recognition of the extended character of a disaster is important for understanding the mechanisms used by Haitian society after the earthquake despite the scarcity of resources and the despair caused by the destruction. Critical events disrupt ordinary everyday life, represent a "breakdown," and configure an important "time marker," but remain paradoxically embedded in the temporal structure of social relations and become assimilated into the experience of daily life.

When inquiring about the impacts of the earthquake, I came across a complex web of situations that linked this event to others. In 2010, two other tragic events severely affected the Grand'Anse region: Hurricane Tomas and a cholera epidemic, with the first case recorded in November. ${ }^{36}$ It was therefore impossible to understand the data available without considering it within a process that involved a succession of catastrophes, a "routine of ruptures" (James 2010). Historically, notions of violence and insecurity have permeated the everyday life of the Haitian people for decades. In the economic and political spheres, we also find an environment of uncertainty that combines various experiences of corruption and exploitation. ${ }^{37}$

In this context, the very idea of "ordinary life" must be questioned; social life is not composed of a daily repetition of procedures. The organization of time follows a distinct course. The vast majority of the Haitian population does not have a regular source of income, which makes the activities of waking up, eating, going to work, returning home and sleeping, not routinized activities. Each day is a new battleground where people fight to survive and to ensure the livelihood of those around them.

In a context marked by structural uncertainty, precariousness, and deep transformations, Haitians have always had to seek shortcuts and improvise to overcome numerous difficulties and obstacles. There is an important relationship between crisis and improvisation (Trajano Filho 2008) that involves the complexity of social life in which change, conflict, and instability constantly intertwine with permanence, integration,

\footnotetext{
36 Haiti had no previously recorded cases of cholera before 2010, when it "was in fact introduced by Nepali MINUSTAH soldiers at the Mirebalais base who had their waste dumped into the Artibonite River by contractors. At the time, Nepal was fighting a severe outbreak of cholera. The strain of cholera matched those found in Nepal, and the Haitian cases were all downstream of the dump sites on the Artibonite River" (Podur 2012: 140).

37 The state, unable to enforce the law and ensure the rights of the population, along with external stakeholders who arouse suspicion even when acting for humanitarian purposes, play an important role in establishing this insecure environment. James defines insecurity as a phenomenon that "incorporates political and criminal violence, economic instability, environmental vulnerability, and long histories of corruption and predation on the part of Haitian and foreign interveners" (2010: 22).
} 
and balance. Agents play an active role in the game when "managing" or "fending for themselves" (degaje), looking for the best ways of life, wherever they are. By doing this, they use the available repertoire and articulate creative schemes, which, however, do not operate in a vacuum.

In this sense, deeply rooted forms of solidarity and strategies that foment cooperation played a major role in ensuring the maintenance of order and survival of the victims. The techniques adopted articulated traditional institutions and practices that form a safety net in uncertain times, mitigating vulnerability. These social networks are more flexible than formal associations and respond more promptly and efficiently to the demands of the people when official institutions break down (Lourenço-Lindel 2001). Particularly relevant were the affective relations of consanguinity and alliances. The uniqueness of the Haitian social dynamic, which has procedurally embedded some practices of the lakou institution, ${ }^{38}$ was responsible for the organization of food production and distribution networks, which were decisive during this time. This dynamic is also associated with the incorporation of a particular meaning of the term "family" and "extended family" that involves a wider and more comprehensive understanding of the concepts of "aggregate", "fosterage", and "neighborhood," all of them fundamental relations of mutuality and moral engagement that played a key role after the disaster. In this context, neighbors who had not received survivors would support others who took displaced people into their own homes, by sharing all sorts of resources.

The international aid system articulates a framework driven by a notion of solidarity, which is defined by the idea of victim, employing a logic that reiterates power disparities between the recipients of help, and those who are in a position to offer the help. The help that determined the fate of those who went to Grand'Anse after the earthquake goes beyond that framework. Only through an analytic emphasis on process that considers both change and continuity can one understand these modes of helping, or networks of reciprocity, that I witnessed in Grand'Anse. The configuration of these reciprocity networks contrasts directly with the more technocratic aid responses defined by the linearity of time and the containment of space (Agier 2008).

The dynamic movement of social actors in shaping networks of mutual help does not stem from a causal chain, but establishes elaborate dialogues informed by past experiences and future expectations. The unspoken help that I have analyzed in this work had at its center Haitians themselves as the principal actors, all of whom were also impacted by the earthquake. In this context, this response has fundamental implications for the resilience of these communities, and their capacity to recover from difficult situations. This dynamic reveals the existence of a logic of giving that is not guided by calculations and utilitarian interests, but by a more complex moral economy.

However, such arrangements of help, despite the quick mobilization, faced serious limitations due to a lack of resources and economic opportunities in the region. The survivors tended to be housed by families for 6 to 24 months. After this period, the vast majority of them had no alternative other than to return to Port-au-Prince.

Received: September 24, 2019

Approved: February 12, 2020

Revised by Jeffrey Hoff

\footnotetext{
38 Rémy Bastien (1951) provides a rich description of lakou and its objective characteristics (a set of houses, in addition to parcels of land for food production and a space for a cemetery) that are linked to alliance rules, rituals and ceremonies, the transfer of property and succession, in which obligations are still established through a parental authority. A lakou is characterized by a principle of social order based on the idea of honor and respect. In this space, harmony is maintained by a constant commitment between individuals and the community that fosters cooperation and a division of labor. Smucker (1983: 112-21) describes the lakou as "the essential social unit of peasant society" in parallel with the habitation's importance to the colonial regime. For another detailed discussion of the meaning and significance of the lakou, see Woodson (1990: 195-206) and Bulamah (2013).
} 


\section{References}

AGAMBEN, Giorgio. 2005. Infância e História: Destruição da Experiência e Origem da História. Editora UFMG: Belo Horizonte.

AGIER, Michel. 2008. Gérer les indésirables: Des camps de réfugiés au gouvernement humanitaire. Paris: Éditions Flammarion.

ALCINDOR, Jean-Pierre. 2011. Jérémie, Haiti... Il était une fois. Port-au-Prince: Média-Texte.

BASTIEN, Rémy. 1951. La familia rural haitiana - Valle de Marbial. México: Libra.

BECKETT, Greg. 2019. There Is No More Haiti: Between Life and Death in Port-au-Prince. Oakland: University of California Press.

BELL, Beverly. 2013. Fault Lines: Views across Haiti's Divide. Ithaca, NY:Cornell University Press.

BENSA, A.; FASSIN, E. 2002. « Les sciences sociales face à l'événement ». Terrain, 38: 5-20.

BERSANI, Ana Elisa. 2015. O (extra)ordinário da ajuda: Histórias não contadas sobre desastre e generosidade na Grand'Anse, Haiti. Dissertação de Mestrado, Universidade Estadual de Campinas - Campinas

BESSIN, M.; BIDART, Claire; GROSSETTI, Michel (eds.). 2010. Bifurcations. Les sciences sociales face aux ruptures et à l'évènement. Paris: La Découverte.

BOLTANSKI, Luc. 1990. L’Amour et la Justice comme compétences: Trois essais de sociologie de l'action. Paris: Métailié.

BOSI, E. 1979. Memória e sociedade: lembranças de velhos. São Paulo: T.A. Queiroz.

BULAMAH, Rodrigo. 2013. O cultivo dos comuns: Parentesco e práticas sociais em Milot, Haiti. Dissertação de Mestrado, Universidade Estadual de Campinas - Campinas

CAILLÉ, Alain; CHANIAL, Philippe, (eds.). 2008. L'amour des autres, care, compassion et humanitarisme. Revue du MAUSS, 31. Paris: La Decouverte.

CAMARGO DA SILVA, Telma. 2005. "As fronteiras das lembranças: memória corporificada, construção de identidades e purificação simbólica no caso de desastre radioativo". Vivência (Dossiê: Memória), 28: 57-73.

CAVÉ, Eddy. 2010. De mémoire de jérémien : ma vie, ma ville, mon village. Pétion-Ville: Les Éditions Pleine Plage.

CHASSAGNE, Albert D. 1977. Bain de sang en Haïti: les macoutes opèrent à Jérémie. New York: Cohen Offset Print.

CHENET, Jean-Baptiste. 2012. “Haiti's Earthquake: A Further Insult to Peasants' Lives”. In: Mark Schuller and Morales Pablo (orgs.), Tectonic Shifts: Haiti since the earthquake. Sterling: Kumarian Press. 97-100.

DASH, J. M. 1981. Literature and Ideology in Haiti 1915-1961. Londres: The Macmillan Press.

DALMASO, Flávia. 2009. A magia em Jacmel: Uma leitura crítica da literatura sobre o vodu haitiano à luz de uma experiência etnográfica. Mestrado em Antropologia Social - PPGAS/MN/UFRJ - Rio de Janeiro. . 2018. "Heranças de família: terras, pessoas e espíritos no sul do Haiti”. Mana, 24(3): 96-123.

DAS, Veena. 1995. Critical Events: An anthropological Perspective on contemporary India. Oxford: University Press.

DEBBASH, Yvan. 1961-2. "Le marronage: Essai sur la désertion de l'esclave antillais", L’Année sociologique, (1961): 1-112; (1962): 117-95.

DORIMAIN, Martin Guiton. 1978. Jérémie d'antan, 1673-1789. [S.I.: s.n.]: Guillaume.

DUBOIS, Laurent. 2004. Avengers of the New World: the Story of the Haitian Revolution. Cambridge: Harvard University Press. . 2012. Haiti: The Aftershocks of History. New York: New York Metropolitan Books.

ESCOBAR, Arturo. 1996. Encountering Development: the Making and Unmaking of the Thirld World. Princeton: Princeton University Press.

FABER, Daniel. 1993. Environment Under Fire: Imperialism and the Ecological Crisis in Central America. New York: Monthly Review Press. 
FARMER, Paul. 2011. Haiti after the earthquake. New York: Public Affairs.

GEBRIAN, Bette J. 1993. Community participation in primary health care in rural Haiti: An ecological approach.

Ph.D. dissertation. University of Connecticut.

GUPTA, Akhil; FERGUSON, James (eds.). 1997. Culture, power, place: Explorations in critical anthropology.

London: Duke University Press.

HALBWACHS, M. 199o. A Memória coletiva. Trad. de Laurent Léon Schaffter. São Paulo: Vértice/Revista dos Tribunais. Tradução de La mémoire collective.

HERSKOVITS, M. J. 2007 (1937). Life in a Haitian Valley. Princeton: Markus Wiener Publishers.

HUNTER, Brian (ed.). 1996-97. The Statesman's Year-Book: A Statistical, Political and Economic Account of the

States of the World. $133^{\text {rd }}$ ed. New York: St. Martin's Press.

HURBON, Laënnec. 1993. "Nationalisme et démocratie en Haïti". Chemins Critiques. Revue Haïtiano -

Caraibéene, 3(1-2):11-27.

JAMES, Erica Caple. 2010. Democratic insecurities: violence, trauma, and intervention in Haiti. Berkeley:

University of California Press.

KATS, Jonathan M. 2013. The big truck that went by: How the world came to save Haiti and left behind a disaster.

New York: Palgrave MacMillan.

LAFERRIÈRE, Dany. 2010. Tout bouge autour de moi. (Collection Chronique). Montréal:

Éditions Mémoire d'Encrier.

LOURENÇO-LINDEL, I. 2001. "Social networks and urban vulnerability to hunger". In: TOSTENSEN,

A.; TVEDTEN; VAA, M. (eds.), Associational life in African cities: Popular responses to the urban crisis, Stockholm: Nordiska Afrikainstitutet.

LOWENTHAL, Ira Paul. 1987. "Marriage is 20, children are 21": The cultural construction of conjugality and the family in rural Haiti. Baltimore: The John Hopkins University.

LOW, Setha. 2009. "Towards an anthropological theory of space and place". Semiotica, 175(1/4): 21-37.

LUNDAHL, M. 1983. The Haitian Economy: Man, Land, and Markets. New York: St. Martin’s Press.

MARCELIN, Louis. 1988. La Famille Suburbaine à Saint-Martin, Port-au-Prince. Port-au-Prince:

Faculté d'Ethnologie/ Université d'État d'Haïti.

MAUSS, Marcel. 1991. (1923-1924) "Essai sur le don. Forme et raison de l'échange dans les sociétés archaiques”. In: Sociologie et Anthropologie. Paris: PUF:143-279.

MCALISTER, Elizabeth. 2012. "From Slave Revolt to a Blood Pact with Satan: The Evangelical Rewriting of Haitian History". Studies in Religion/Sciences religieuses, 41(2): 1-29.

METRAUX, Rhoda. 1951. Kith and kin: a study of creole social structure in Marbial, Haiti. Nova York: Columbia University.

MIDY, Flanklin. 1993. "La question nationale haïtienne". Chemins Critiques. Revue Haïtiano Caraibéene, 3(1-2): 31-70.

MINTZ, Sidney. 1961. "Pratik: Haitian personal economic relationships". In: V. E. Garfield (ed.), Proceedings of the American Ethnological Society. Seattle: University of Washington Press: 54-63.

. 1971. "Men, women and trade". Comparative Studies in Society and History, 13(3): 247-269.

PERRIER, Rose Marie. 1993. Sur les rives du passé: essai historique d’un coin de mon pays. [Port-au-Prince?]:

Editions des Antilles.

PODUR, Justin. 2012. Haiti's New Dictatorship: the coup, the earthquake and the UN Occupation.

United Kingdom: Pluto Press.

POLLAK, M. 1986. "La gestion de l'indicible". Actes de la Recherche en Sciences Sociales, 62/63: 30-53.

REVET, Sandrine. 2018. Les Coulisses du monde des catastrophes «naturelles ». Paris: Éd. de la Msh. 
SAINT MERCY DE, Moreau. 1982 (1797). Description Topographique, Physique, Civile, Politique et Historique de la Partie Française de L'Isle de Saint-Domingue. Port-au-Prince: Le Natal.

SCHULLER, Mark. 2012. Killing with kindness. New Brunswick, EUA: Rutgers University Press. .; MORALES, Pablo (eds.). 2012. Tectonic Shifts: Haiti since the earthquake. Sterling: Kumarian Press.

SMITH, Jennie Marcelle. 2001. When the hands are many: community organization and social change in rural Haiti. Ithaca: Cornell University Press.

SMITH, M. 2004, "Vive 1804 ! : The Haitian Revolution and the Revolutionary Generation of 1946 ". Caribbean Quarterly, 50(4): 25-41. . 2009. Red \& Black in Haiti. Radicalism, Conflict, adn Political Change 1934-1957. Chapel Hill: The University of North Carolina Press.

SMUCKER, Glenn R. 1983. Peasants and Development Politics: A Study In Haitian Class and Culture. Ph.D. dissertation, New School for Social Research.

SOROKIN, P. A. 1942. Man and society in calamity: the effects of war, revolution, famine, pestilence upon human mind, behavior, social organization and cultural life. New York: E. P. Dutton and Company.

TARTER, Andrew. 2015. "Trees in Vodou: An Arbori-cultural Exploration." Journal for the Study of Religion, Nature, and Culture, 9(1): 87-112.

THOMAZ, Omar R. 2010. "O terremoto no Haiti, o mundo dos brancos e o Lougawou". Novos Estudos Cebrap, 86: 23-39.

. 2011. "Eles são assim: racismo e o terremoto de 12 de janeiro de 2010 no Haiti". Cadernos de Campo, 20: $273-284$.

TRAJANO FILHO, Wilson. 2008. "O precário equilibrio entre improvisação e regras: reflexões sobre a cultura política da Guiné-Bissau”. Revista de Antropologia, 51(1): 233-266.

TROUILLOT, Michel-Rolph. 1990. "The Odd and the Ordinary: Haiti, the Caribbean and the World". Cimarron, 2(3): 11 .

WOODSON, Drexel G. 1990. 'Tout Moun Se Moun, Men Tout Moun Pa Menm': Microlevel Sociocultural Aspects of Land Tenure in a Northern Haitian Locality. Ph.D. dissertation, University of Chicago.

Ana Elisa de Figueiredo Bersani

PhD Student in Social Anthropology (PPGAS/UNICAMP)

Graduate Program in Social Anthropology, State University of Campinas, Campinas/SP, Braszil https://orcid.org/0000-0003-1894-3093

Author's Email: anabersani@hotmail.com 